\title{
INFORMATION TECHNOLOGY MANAGEMENT SYSTEM: AN ANALYSIS ON COMPUTATIONAL MODEL FAILURES FOR FLEET MANAGEMENT
}

\author{
Jayr Figueiredo de Oliveira \\ Getúlio Vargas Foundation, São Paulo, São Paulo, Brazil \\ Marcelo Eloy Fernandes \\ Nove de Julho University, São Paulo, São Paulo, Brazil \\ Carlos Roberto Camello Lima \\ Methodist University of Piracicaba, Santa Bárbara d'Oeste, São Paulo, Brazil
}

\begin{abstract}
This article proposes an information technology model to evaluate fleet management failure. Qualitative research done by a case study within an Interstate Transport company in a São Paulo State proposed to establish a relationship between computer tools and valid trustworthy information needs, and within an acceptable timeframe, for decision making, reliability, availability and system management. Additionally, the study aimed to provide relevant and precise information, in order to minimize and mitigate failure actions that may occur, compromising all operational organization base functioning.
\end{abstract}

Keywords: Computer System, Control System, Information Management, Information Technology, Maintenance Management.

\section{RESUMO}

Este artigo propõe um modelo de tecnologia de informação para avaliação de falhas na gestão de frotas. A pesquisa qualitativa realizada por um estudo de

Manuscript first received/Recebido em 22/11/2011 Manuscript accepted/Aprovado em: 19/07/2013

Address for correspondence / Endereço para correspondência

Jayr Figueiredo de Oliveira, Pesquisador da EAESP-FGV. Pós-Doutorado em Administração Administração de Tecnologias da Informação (EAESP-FGV); Doutorado em Educação (PUC-SP); Mestrado em Administração e Planejamento (PUC-SP) e Bacharelado em Administração de Empresas (UNILUS), MBAs em Gestão de Tecnologias da Informação (UNI-FMU) e em Inovação, Tecnologia e Conhecimento (FEA-USP). E-mail: jfigueiredo@usp.br

Marcelo Eloy Fernandes, Professor e coordenador do Curso de Superior de Tecnologia em Gestão da Qualidade da Universidade Nove de Julho. Doutorado em Engenharia de Produção (UNIMEP), Mestre em Administração de Empresas (FECAP), Bacharelado em Análise de Sistemas (UNIP). E-mail: marceloeloyfernandes@uninove.br

Carlos Roberto Camello Lima, Doutorado e Mestrado em Engenharia Mecânica (UNICAMP). Professor Titular da UNIMEP, Pós-doutorado em Engenharia e Ciência dos Materiais (SUNY - State University of New York) e Ciência dos Materiais e Engenharia Metalúrgica (UB - Univ. de Barcelona). Graduado em Mecânica (UNESP) e Ciências Econômicas (UFS - Universidade Federal de Sergipe). E-mail: crclima@unimep.br 
caso numa empresa de Transporte Rodoviário Interestadual no Estado de São Paulo, propôs estabelecer relações entre as ferramentas computacionais e a necessidade de informações, fidedignas e em intervalos de tempo aceitáveis como válidas, para as tomadas de decisão, confiabilidade, disponibilidade e gestão de sistemas. Adicionalmente, o estudo visou fornecer informações relevantes e precisas, de forma a minimizar e mitigar ações de falhas que possam ocorrer, comprometendo o funcionamento de toda a base operacional da organização.

Palavras-chave: Sistema Computacional, Sistema de Controle, Gerenciamento de Informação, Tecnologias da Informação, Sistemas de Informação.

\section{INTRODUCTION}

The hereby article presents a computational model for evaluating failures within the Interstate Road Transport System management, typified as a critical operational process.

This computational model is being idealized according to the latest transformations going on in the organizational scenario, where companies need to keep their competitive edge. Customers are their main target, thereforeimplementing strategic actions becomes an essential step towards contributing to an optimized Maintenance Management with a highly reliable processes expectation, preventing impacts and further charges with products and/or provided services.

Souza and Lima (2003) agree with this guideline which, among other proceedings, was adopted by world-class companies as a manner to ensure their survival and competitiveness along with the consequent market growth - the RCM (Reliability Centered Maintenance methodology) process remains.

On JQME's (2010) concept, the continuous search of companies for cost reductions has required the adoption of severe measures regarding their industrial maintenance plans, mainly by retrenchment of excessive inventory replacement parts and upgrading productivity levels along with company's quality.

In this context, maintainability needs to be examined as an important function amid strategic politics towards extracting results from organizations, thus enabling companies to reach competitive market levels alluding to quality and productivity.

\section{Objective}

The general goal of this article is to propose a computational model, working as a support and assistance for previewing and anticipating the decision-making moment in transactional processes, with a focal point on a service provider organization of the Interstate Road System for Public Transport.

\section{Arguments}

This survey was based on the bellow enumerated aspects:

1) Reduced number of research dealing with the herewith proposed problem; 
2) Priority resulting from aspects that could bring about damages to human life and consequently, financial and economic loss to organizations;

3) And finally, on the hampering of integration regarding scattered information amid multiple computational systems, resulting on delays and problematic decision-making.

Thus, this survey's distinctive proposal, while facing analysis that deals with Reliability Centered Maintenance, relies on the fact that they generally have no consideration towards developing an integrated computational model, whose proposal would be to investigate methods with a focal point on Maintenance Management, strictly speaking, maintenance throughout an operational cycle with broader efficiency and competence.

Service providers for the Road Transport System in general and also for those covering longer distances, like the Interstate Road Transport System, demonstrate operations that need, as for performance dominant factors, high availability and reliability. The final consumer for this type of business is inclined to give negative evaluations to variables derived from mechanic failures, lack of maintenance or the unavailability of an appropriate maintenance program.

For the above reasons and because of the gaps left in previous surveys made in this field, the herewith research is developed in order to classify the actual occurring variables, the scenario within and which the recommendations to minimize occurrences linked to procedure failures are.

Therefore, the first argument towards this research shows that after an extensive revision of the literature on Reliability Centered Maintenance and employment of Business Intelligence Technology, it was observed that until then, some issues had not been duly emphasized while indicating specific utilization of resources for Information Systems and computational models, supporting decision-making for projects of maintenance systems targeted towards the Road Transport System segment.

Some surveys and surveyors stand out when the matter deals with understanding the relation between maintenance and the adoption of Information Technology. In order to exemplify this, we have Campos' (1999) proposal, which deals with the employment and support of Information Technology, aiming for problem solutions to fleet vehicle maintenance management based on a knowledge management system.

Furthermore, there is research supporting the first argument, such as research by Almeida Junior (2003), Oliveira (2010) and Santos (2001), who respectively depict comparisons between maintenance variables in information security systems, the correlation between resource dynamics and information system tools for subway transportation systems. Also through considerations on maintenance processes for bus operating companies, it was perceived that this survey highlights differing perspectives from those originally aimed for this research.

On the other hand, the second argument for this study is produced through the awareness that human life is the most important heritage at all times; therefore, assuring integrity, security and reliability for maintenance systems that concern human life ends up being a fundamental consequence.

Lastly, the third argument is based on the privation of integration between maintenance systems and decision-making support systems. Whereas, when information 
is found scattered throughout diverse computational systems, it becomes an obstacle for distinguishing the level of importance that an injury/accident indicator supervisor has.

Facing the context of the above exposed matter, the argument of this study relies on the interdisciplinary contribution of showing a proposal to disseminate theoretical fundamentals and good managerial practices while using system tools that support decision-making in organizations, as a basis for their day-to-day business and operations.

Thus, what remains is a search to legitimize an efficient adoption of information systems supporting decision-making and expressively helping to upgrade actions, on the matter of maintenance systems for the Road Transport System segment.

\section{RESEARCH PROBLEM}

According to Nunes and Valladares (2002, p.19), "RCM is configured as a strategic and organizational tool of the maintenance field that adds value to the productive process".

This means that the triple combination generated by a technical equipment performance, allied to professional knowledge of those in charge, handling with decision-making tools aligned to organizations' strategy, brings forth confidence and reliability to the operation, improves operational cost management, allowing to reduce failures and occurrences with maintenance.

Facing this line of thought, this research addresses this issue with the following question: "What would be the feasibility of implementing a computational model that generates performance and unforeseen indicators for Road Transport System, characterized as an essential process for your operation?"

\section{BIBLIOGRAPHIC REVIEW}

Centering the hereby paper, we will hither initiate a brief review of the applied concepts of maintenance, whose activities have been increasingly prized within organizations. The review focuses on the importance of the maintenance function to prevent or to avoid failures and damages, consequently resulting in quality improvement, while reaching productivity gains for companies.

\section{Maintenance Overview}

Maintenance activities have the purpose of keeping equipment in suitable conditions for operating. These activities may be classified as: planned and not planned corrective maintenance; preventive maintenance; predictive maintenance; detective maintenance and maintenance engineering (Pinto and Xavier, 2001).

Thus, understanding that Planned Corrective Maintenance is a correction carried out from a predictive monitoring through managerial decision making, that is to say, performance on the basis of predictive monitoring or the choice to operate until damaged. Moreover, unplanned corrective maintenance happens when it is noticed that the equipment is not producing as expected, owing to its characteristics relying mainly on the maintenance performance of an event that has already occurred, generally resulting in high costs for the company (Pinto and Xavier, 2001). 
According to Siqueira (2009), preventive maintenance enables support in conformance with a pre-established schedule presented by the company, aiming to lessen errors and costs, including performance decline. Its execution is focused on minimizing probabilities for equipment failures.

Predictive maintenance aims for the performance of maintenance, only when equipment needs so (Slack, Chambers and Johnston, et al., 2007). Hence, predictive or supervised maintenance identifies incipient failures before they may even become critic; thus, permitting a most precise planning.

Detection maintenance, in general, searches for hidden irregularities that were undetected by equipment or the system operator, usually related to command or to a protection system (Pinto and Xavier, 2001).

Maintenance Engineering incorporates criteria that increase guaranteed availability and reliability amid maintenance activities, where planning and control are developed with the intention of predicting or previewing failures and further optimizing performance of the maintenance production teams. Concluding, they are assignments that develop, implement and analyze results through computerized maintenance management systems (Pinto and Xavier, 2001).

\section{Reliability}

Based on constant incidents, around the year of 1950, with failures and diminishment of availability for the electronic systems of the military field, reliability emerges as a topic of interest in the United States of America. This situation has inclusively driven the United States Department of Defense and the electronic industries to create a survey group to research on the subject of reliability (Villemeur, 1992).

Reliability is understood as something that causes a system to work accordingly to what they were designed for, under particular conditions and during a specific period of time (Son, et. all, 2009).

Also, the purpose of Reliability Engineering is to identify failures in system modules that are considered critical, aiding further so that these failures do not happen at an operational level (Rausand and Hoyland, 2004).

Conversely, we have the safety that corresponds to the probability of an operating system complying correctly with its duty. Amid extremely risky systems, both functional and informational security is present, being the latter a protection against failures affecting the entire system safeguarding data integrity.

As far as this is concerned, the Road Transport System may use automatic controls to help activate system security mechanisms, keeping in mind the probability of human failure incidences; thus, preventing accidents.

Security terms for high risk systems are commonly used, as follows: exposure; vulnerability; attack; threats; control (Sommerville, 2007).

But when dealing with risk control management, the term ALARP - As Low As Reasonably Practicable (see Figure 1), though seldomly used, is of great utility and may be observed as a guideline for adopting control strategies for risk reduction. 


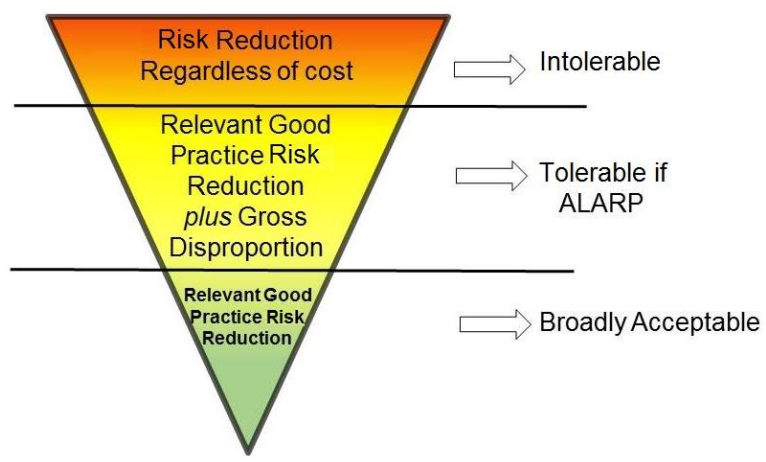

Figure 1 - ALARP Principle.

Source: (IEC, 1997)

It is understood, that the Interstate Road System is a freeway network classified by a high level of accidents and it needs to count on an essentially reliable service in order to transport human lives.

\section{Reliability Centered Maintenance}

Failure mode effects that may incidentally occur during a productive process, together with equipment, functions and inter-relations belonging to this field, deserve special attention from the maintenance area.

According to Marçal and Susin (2005), "an effective maintenance process includes all the technical and organizational activities that may guarantee the expected reliability for operating machinery and equipment in general." Maintenance and repairing works that follow particular basic guidelines reduce the chance of having unexpected failures and, as consequence, loss of production, time and unnecessary expenses.

On the other side of the fence, equipment must receive a different treatment, based on their needs and specific importance, thus generating distinctive maintenance policies for different groups of equipment.

According to Siqueira (2009), "one of the characteristics of the Reliability Centered Maintenance (RCM) is to provide a structured method to select maintenance activities for any productive process."

With RCM, working groups can dedicate themselves to upgrading levels of equipment reliability, while concentrating efforts on machinery considered as priority inside the factory structure.

One of the RCM application potentials is by obtaining a maintenance plan with an efficient cost. This method recovers and systematizes knowledge from those involved in its process, thus generating a greater commitment over the performed work. 


\section{Data Management and Information Technology}

This topic provides information of systems supporting managerial decisionmaking, along with company's data which are integrated to operational systems, with the aim of improving its performance and reliability.

\section{Data Warehouse}

In order to obtain competitiveness and profitability, companies need to control their decision-making process through a faster pace; thus, they need to react with increasing agility while changing their environment, which usually happens through analysis, scheduling and performing tactical actions or suitable strategies.

O' Brien (2008) has reported that a Data Warehouse stores information from current and later years, drawn from various operational data banks of an organization. It is basically an already classified, edited, standardized and integrated central data source, that may be used by managers and other final pro users, for a wide range of arrangements and business analysis, market research, and decision-making support.

This resource integrates and consolidates information for various collections; it also dimensions and consolidates data, organizing it with the aim of improving consultation performance. Namely, the Data Warehouse may be considered as a factory of enterprise information .

Kimball (1998) specifies some goals for a Data Warehouse; the main ones are:

a) Provide organizational or corporate data access;

b) Keep reliable and consistent data, in accordance with the company's criteria;

c) Separate, combine and catalogue data so to facilitate and be available for any possible visions of business;

d) Supply means for consulting, analyzing and presenting information;

e) Guarantee reliable data publishing; to assure data quality in order to support business re-engineering.

\section{Data Mart}

Data Mart makes part of a Data Warehouse. Even though it has a small capacity, its employment attends a department of the company with the same characteristics of the Data Warehouse (Singh, 2001).

Data Mart is denominated this way because it was created from a Data Warehouse with an enterprising scope, where a central data warehouse serves the whole organization or where it creates smaller decentralized warehouses which are the so called Data Marts.

Data Mart usually focuses on a single area of interest or a specific business line, thus permitting it to be set up at a faster pace and at smaller costs, compared to setting up a Data Warehouse with an enterprising scope.

\section{Data Mining}

Data Mining storage capacity goes through an everyday challenge, because there is a major growth of data available. So that Data Mining along with all its tools enables a data "mining", in order to generate a solid value of facts, transforming them into 
knowledge and information. As far as this is concerned, Data Mining may be looked at as a method that searches and detects logic or mathematical descriptions, which are often of complex nature, with sequences and orderliness in a set of data search detecting patterns, associations, adjustments, anomalies, statistic structures and data events.

Data Mining has the following purposes (Elmasri and Navathe, 2002):

a) forecasting - demonstrating how certain attributes will be behave in the future;

b) identifying - the data pattern is used to identify the existence of an element, situation or activity;

c) classifying - data is categorized into different classes and identified based on a combination of parameters;

d) optimizing resources.

\section{BSC (Balanced Score Card)}

In order to measure a company's performance, a financial report is usually employed based on assets that enable showing profits or losses; however, the intangible assets have nowadays also become a source of competitive advantage.

So the Balanced Scorecard (BSC) emerges, a strategic tool that employs elements capable of supplying such demands. Kaplan and Norton (1997, p. 08), exemplify that:

"Financial measures reveal the history of past events, an adequate account from companies of the industrial era, when long-term investment capacities and customer relationships were not fundamental for success."

According to Kaplan and Norton (1997, p. 08), “A Balanced Scorecard structure is formed through four perspectives: financial, clients, internal processes, and strategic training and growth."

$B S C$ is focused on a search for financial objectives, and also on attributes embedded in the company's mission, and they are a reflection of the vision and strategy of the organization for all the four dimensions of this appliance and thus, for each perspective, besides objectives, goals must be established, and procedures and performance indicators implemented.

Hence, the system enables administrators with a financial performance followup of the company, auditing alongside the growth process for capacity construction. In other words, aligning the current performance and focusing on future performances of the company, thus encouraging managers to direct their attention to factors that conceive economic value.

Operationally speaking, these indicators distributed amongst four managerial processes, which contribute to long-term strategic goals bound to short-term actions, precisely, it explains and interprets strategy and vision; communicates and associates objectives and strategic measures; plans and establishes goals aligning strategic enterprises; improves feedback and strategic apprenticeship.

\section{Computational Environment Proposal}

This item demonstrates the development of an itinerary for the computational model of maintenance focused on reliability, correlating them to Kimball's (1998) nine 
steps. It performs the display of a pattern and describes the proposal for generating probability indicators for Road Transport System. Further still, it provides support and outlines the initial feats of the Brazilian Interstate Road Transport System.

\section{General Script Elaboration}

While elaborating a script for a computational model for maintenance management focused on reliability, Kimball's (1998) nine steps may be useful; considerations are described $\mathrm{o}=\mathrm{un}$ the stages below:

$1^{\text {st }}$ ) Choosing process - process is selected (or functions) on a Data Mart subject in particular;

$2^{\text {nd }}$ ) Choosing granularity - based on the former chosen stage, granularity of elements to be stocked is chosen and a fact table is developed;

$3^{\text {rd }}$ ) Identifying dimensions - constructing a list of dimensions so to determine the context of questions about facts at the fact table;

$4^{\text {th }}$ ) Choosing facts - granularity of the fact table determines facts that may be used at Data Mart. All facts should be expressed at the suggested level by granularity;

$5^{\text {th }}$ ) Stocking preliminary calculations in the fact table - once facts are selected, they should be reexamined in order to determine whether there is a chance of using preliminary calculation;

$6^{\text {th }}$ ) Dimension table rounding off - return to dimension tables and add the highest possible text descriptions to dimensions;

$7^{\text {th }}$ ) Choosing data bank duration - decisions on data records life cycle. The duration refers to the length of action of the fact tables;

$8^{\text {th }}$ ) Determining dimensional changes - stocking old dimension descriptions should be used as a record of former transactions;

$9^{\text {th }}$ ) Deciding on consultation priority - subjects that are considered as critical should be studied and treated while assembling Data Mart, pursuing utmost security on transactions.

\section{General Itinerary for Development and Performance Indicators}

It is within this topic that we will locate the description of a proposal on contingence indicators planning for Road Transport System. In its core, the proposal gathers a set of information that represents in a detailed manner, operational processes, implicated computational resources, a main source of information assortments, as well as an analysis of the main points of failure for the surveyed model.

In order to be able to analyze questions on the technical and functional feasibility of this paper, we have managed to develop a diagram, shown in Figure 2, in such a manner as to represent the hierarchy of logic steps towards the stages of each assignment, as follows: 


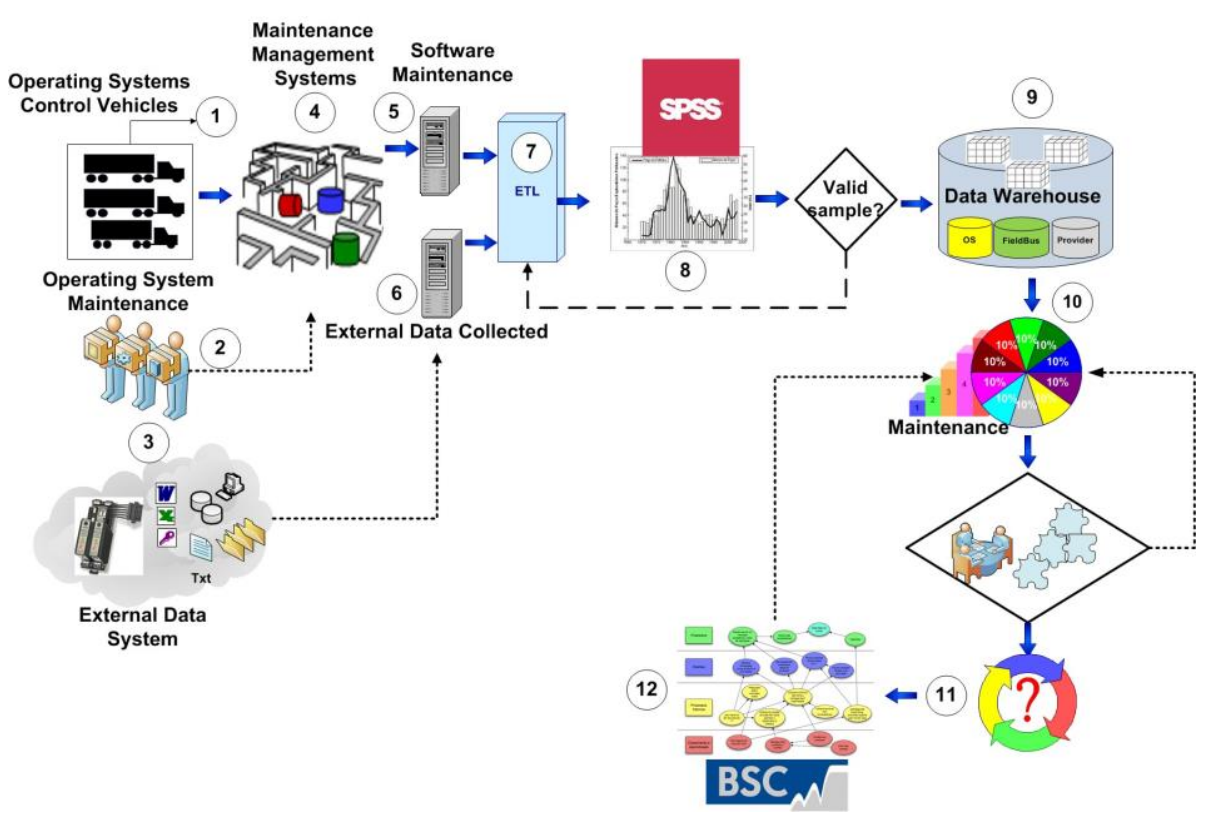

Figure 2 - Computational Model for analyzing Maintenance Indicators

Source: (Authors, 2010)

- Failures and information supply sources: starting from the sketching and auditing of procedures done in the company, aligned to people concerned with maintenance management and operations, it was possible to detect that the main failure sources were among operational systems for vehicle control (1), maintenance operational systems (2), and the external data system (3), that contain data on the electronic reading system installed inside the company's vehicles. Incidences generated from the external data system did not gain a direct access, bearing in mind that this system does not make part of the company's conventional net, since it is a highly available system. However, all the failures detected by the operational control system were registered at the external data providers and maintenance (5 and 6), as well as registered data into work order for a future historic evaluation.

- Collection process, handling and data transference: all collection processes, handling and data transference from system data (4, 5 and 6$)$ are done twice a day by the ETL tool (7) (Extracting, Transforming and Loading), thus ensuring, that the character of the imported information is consistent, upstanding, correct, complete, not redundant and adherent to decisionmaking through the company's needs.

- Data storing: after the ETL process (7), data is stored on the server (8). The collected data from maintenance transactional systems is stored in the form of selected dimensions, each one set in their own dimensional model inside the Data Warehouse (8).

- OLAP (On Line Analytical Processing): along with data already available in the Data Warehouse (9), the organization's managers (10) may begin strategic modeling for decision-making through graphic consultation and/or personalized reports, molded through the organization's needs. 
- Feedback process: after an analytical search through the OLAP (On-line Analytical Processing) layer (9), expectations towards secure strategic decisionmaking, guarantee actions directed to system quality upgrading.

It may be observed that the above described environment has made the information cycle generated by the company most likely to be understood, as well as facilitating visualization and accomplishment of possible testing on analytical and decision-making processes, made necessary in this paper. It is expected, in this particular case, a half day break for updating information on the analytical environment, thus meeting the expectations of participating managers for the company decisionmaking process.

The concept of Reliability Strategic Indicators (Indicadores Estratégicos de Confiança (IEC)) is originated from the survey and definition of the following authors: Kaplan and Norton (2000), who utilized the BSC (Balanced Scorecard) method, as a main factor for the Key Performance Indicators (KPI) search. We must hereby highlight that the hereby handled Strategic Indicators were evaluated and adjusted in accordance with the reality of this case survey. As represented in Figure 3, the indicators of this survey have established technological parameters for factors related to acquisition, implantation, expansion and the pursuit of modernizing the current equipped systems of the company. Still on the maintenance point of view, strategies related to maintainability and reliability of equipment operating in corporations were duly defined.

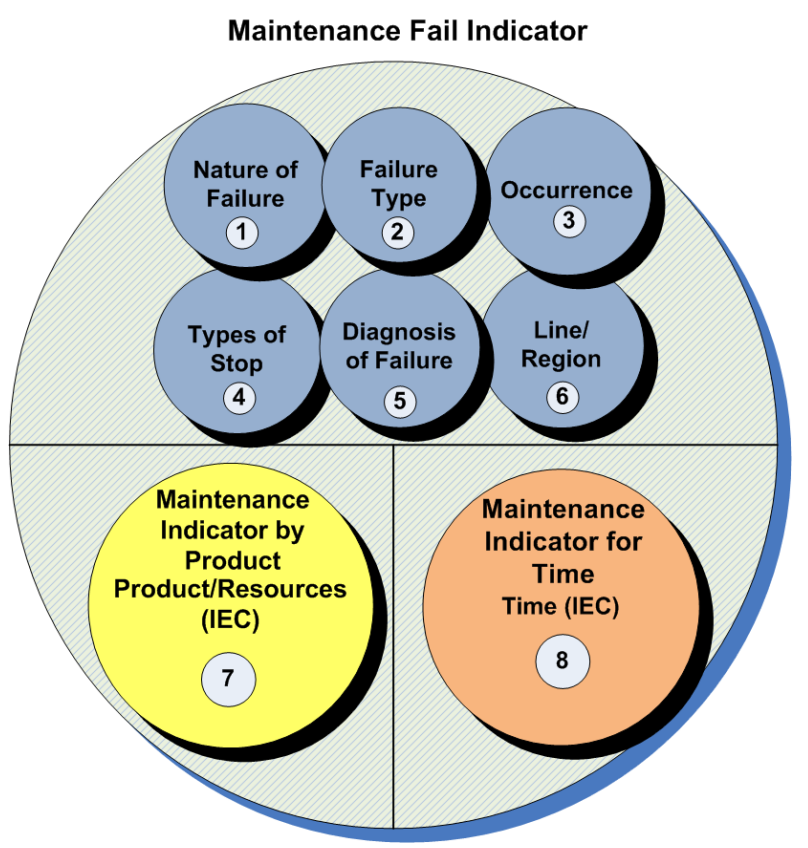

Figure 3 - Strategic Indicators Applied to Maintenance.

Source: (Authors, 2010)

Proceeding, Strategic Indicators will be described, suggested and extracted from this case survey, as follows:

$1^{\circ}$ ) Failure Aspect Indicator (1): this indicator is related to the intersection of occurrences with Aspects and equipment Failures; 
$\left.2^{\circ}\right)$ Failure Type Indicator (2): this indicator is related to the type of failure occurring with equipment, measured by the mode (mechanic, electric, structural and human failure, ) by type of failure (ductile, fragile, fatigue, thermic fatigue, mechanic fatigue, electric fatigue, corrosion, abrasive, pressure, torsion, magnetic, overcharge, over-tension, knowledge, attention and deterioration);

$3^{\circ}$ ) Occurrence Indicators (3): this indicator deals with items like work order numbers, type of service, among other;

$\left.4^{\circ}\right)$ Halt Indicators (4): this indicator deals with halt cases checking for errors (repair, test, alignment, calibration, lubrication, revision, caster, adjustment, replacement, cleaning, etc.);

$5^{\circ}$ ) Failure Diagnosis Indicator (5): this indicator identifies failure diagnosis symptoms that are related to: overheating, electric crash, highvoltage, motor abnormal noise, viscosity, wheel abnormal noise, smoke, pigmentation, coloring, improper signaling, fairing abnormal noise, electric charge evasion, abnormal trepidation, loss of pressure, oil odor, etc.;

$\left.6^{\circ}\right)$ Line/Region Indicator (6): this item highlights granularity of data related to line number, origin, destiny, region and distance between origin and destiny;

$7^{\circ}$ ) Product $\mathbf{x}$ Resource Indicators (7): this indicator rescues groups of products: air-conditioning, cooling device, gearbox, chassis, differential, steering wheel, electric components, brake, metal repair, cleaning, motor, rolling and suspension; related to products;

$8^{\circ}$ ) Time Indicator (8): this indicator is valid through time variable, according to established: year, semester, trimester, two months, month, fortnight, week, days, hours and minutes; other variables are - still hours, hours of service attendance, standby hours, preventive hours, availability, occurrence hour, etc..

\section{METHODOLOGY}

According to Godoy (2007), there are three possible methods to carry out a qualitative research: documental research, case study and ethnography. The hereby adopted qualitative method will use a case study from a company located in the whereabouts of São Paulo, whose operational process meets with the proposal of this project, in other words, it includes critical and complex operations for the Interstate Road Transport System mode.

As reported by Miguel et.al. (2010), "amid the qualitative viewpoint, the subjective reality of individuals involved in the survey is considered relevant and contributes to the development of the survey."

The survey is made with a big sized organization, whose segment is the Interstate Road Transport System. The hereby sample is according to the required profile for this study, since it works inside an environment where total reliability is a must for management and application of their operational processes. 
Nowadays, the company has significant expenditures with maintenance due to its inherent critical condition, a justification towards which implementing a system that integrates their equipment to a RCM management with a more precise communication net would definitely enable a substantial expense decrease.

Motivated by this case study and with the implementation of a computational model, it is estimated that this company will be able to save expenses with maintenance, which will possibly be progressively reduced and shown during the course of this survey.

According to Miguel et.al. (2010) "among the main benefits of leading a case study is the possibility of developing new theories and increasing understanding towards genuine and contemporary events."

Originally, data collection happens by attaining information from the maintenance staff, by means of a previously obtained historical record. Equipment has failure records sourced from their last three years of operation. However, we will only take in consideration components with higher levels of failure propensity and consequent influence on the operational cycle halt, generating high maintenance costs and production loss for this company.

This information will be stored into the RCM programs and integrated to Communication Nets, thus, enabling in advance the delivery of information to the Maintenance Engineering, reporting any situation involving excessive usage or an $80 \%$ useful life cycle, proceeding without ceasing the operational cycle.

Equipment records should also be obtained from suppliers in a detailed manner, so to include every single part of the equipment and accessories considered as most urgently important in terms of maintenance when submitted under stressing conditions, as critical process cases may be.

Under Gil's (2002) opinion, "researches may be classified following the proposed objectives and/or with the employed techniques and procedures. Regarding objectives, researches may be exploratory, descriptive or explanatory."

Further in this paper, we further adopt "Theoretical Reference" for the Bibliographic Research, which is a work development whose research problem requires a mere theoretical approach. Although, with almost all research works it becomes necessary some type of labor of this nature, as bibliographic research in this undertaking is exclusively developed from bibliographic sources or papers.

In turn, the researched company's profile in this paper belongs to the Interstate Road Public Transport, which already has fifty years of activity in the Brazilian market.

The company headquarters is located in the Northern region of São Paulo city, near the great Highway Service Centre of the city, which remains as a competitive determinant and distinctintive center, because of the easy availability of vehicles. The service is offered to most of the interior cities and Capital of São Paulo State, owning a fleet of approximately 1,235 buses.

One of the characteristics of this bus fleet is providing comfort to the customer; by aiming at this; the fleet is equipped with modern video and music center equipment, air-conditioning and constant investments with the acquisition of new vehicles. 
Regarding considerations with security and bus maintenance, the company usually renews its fleet every two years and executes maintenance after $15,000 \mathrm{~km}$ of road running for new vehicles; for those vehicles which have already ran a bit more, maintenance is done after $8,000 \mathrm{~km}$, according to indications of the Instruction Manual.

Being the company's maintenance area the most important and best equipped section, investments are very elevated, roughly $\mathrm{R} \$ 15$ million with components, replacement parts, automation and maintenance fleet management.

The corporate philosophy is that all buses should be submitted to a general revision after ending the day's route; further still, there is a training-bus project that runs throughout the country (Brazil) retraining mechanics and drivers.

The company currently employes more than ninety employees to manage the organization's maintenance; these employees include from mechanical engineers to mechanics trained at the bus supplier's factory, both with lots of operational and business experience.

Buses run up to $900 \mathrm{~km}$ of daily journeys, serving millions of people traveling from their homes to other states and municipalities that are very distant from the State of São Paulo. Although the company worries mostly about their service quality, many of the maintenance services are still done through manual work orders, which are transcribed to spreadsheets, generating error probabilities and delays for the decisionmaking processes.

Another important aspect to be highlighted, for the in loco visit done biweekly at the organization since 2009, is the fact that fleet vehicles, manufactured between the years of 2008 and 2010, already have a Fault Detection technology installed within them (Fieldbus). Consequently, it has been possible to collect incidents and failure statistics data directly from the source, through reading the application software embedded in the Fieldbus Pattern and language based on an eXtensible Markup Language (XML) Technology.

Subsequently, this information could be transferred to the database of a maintenance control system, where they could be evaluated through a distribution and correlation analysis with their own software. Hence enabling scores and creating a suitable environment for analyzing reliability, thus identifying existing mechanism failures within the installations and probable statistic tendencies.

\section{OUTCOME}

This Balanced Scorecard was highlighted from results obtained throughout various tools used during the development of this paper, with which the company's board of directors, management and technical staff carried out many meetings during December 2009, to score through future workable goals to be practiced from January 2010. Figure 4 represents the hereby mentioned strategic map: 


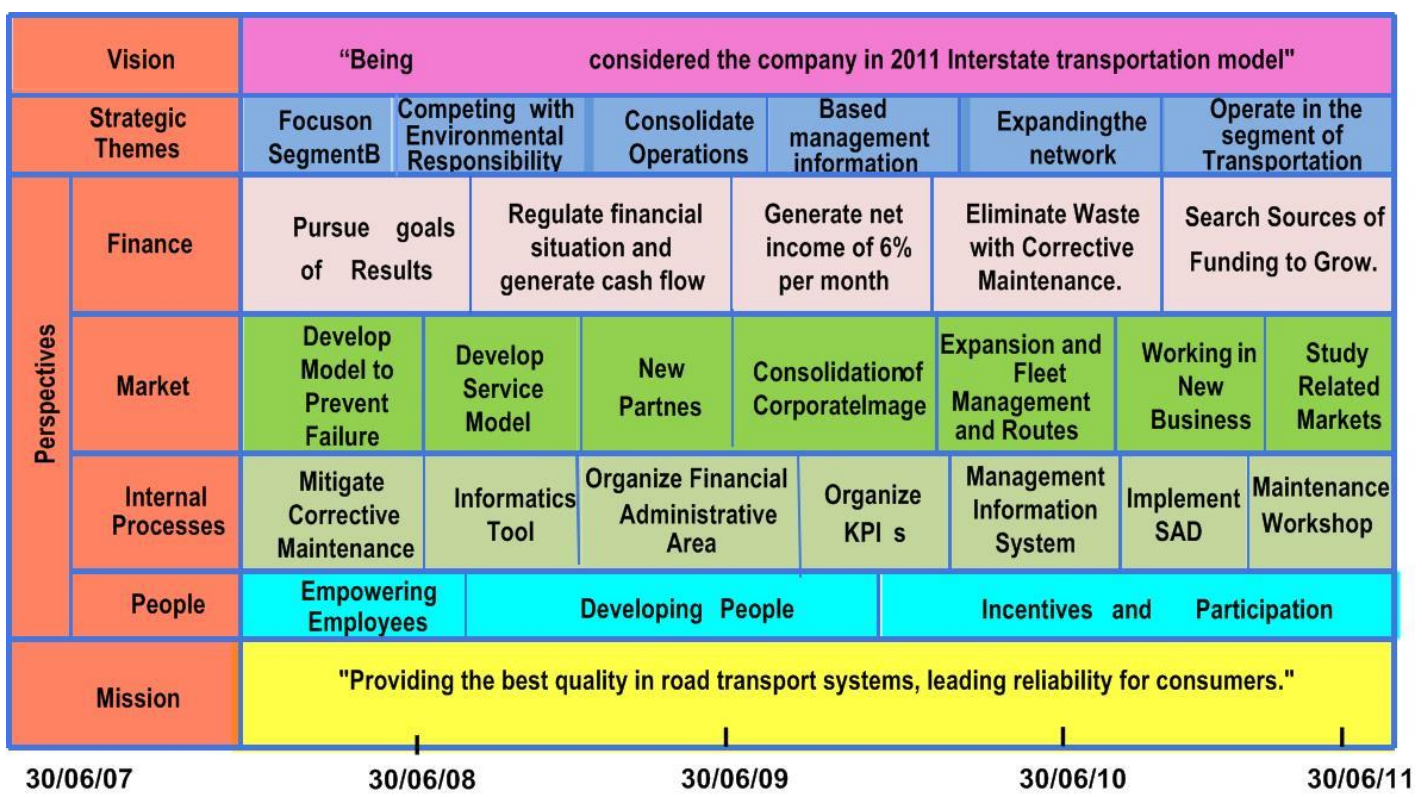

Figure 4: Balanced Scorecard.

Source: (Authors, 2010)

This scoreboard, originated from various debates, illustrates the main points to be worked on, so that the company may be definitely considered a model for the Interstate Transportat System segment, thus providing better quality services to consumers.

Amid this scenario, the managers have structured the above mentioned scoreboard within four perspectives: Financial; Market; Internal Processes and People.

As for Financial perspectives, there are five aspects to be taken in consideration: aiming effective outcomes (sales increase, growth and profits); regulating the financial situation and generating cash flow; producing a $6 \%$ liquid profit per month and saving a part of it for expansion; eliminating squandering with corrective maintenance actions; and searching for financing sources in order to grow and expand into new markets.

Within this context, when the subject is maintenance, enterprise managers have perceived that many problems related to this subject are due to a lack of systems with the ability of signalizing the company's actual situation and with the capacity to also integrate all types of information.

Regarding to Market perspectives, managers have delineated seven important parameters, as follows: developing a preventive model for failures; developing service models; new partners working towards the construction of a consolidate enterprise image; expansion planning and fleet and route management; new businesses scheming; and analyzing correlative markets.

These guidelines are intrinsically linked, since all problems that the company had been facing in a recent past and which had been provoking negative consequences, were directly linked to its maintenance; from then on and in order to improve their market image, they begun to develop a new failure prevention model, with a $\mathrm{R} \$ 7$ million investment on Technical Support Systems and Information. Thus new failure prevention models were designed, causing faults to be examined and noticed 
beforehand, together with service models developed and performed to work efficiently faster.

It has become evident that regarding Internal Processes, managers have started to worry about: Corrective Maintenance; consolidating Informatics application and tools; organizing the financial managerial field; structuring performance indicators; implementing information management; implementing SAD; and organizing mechanical workshops and maintenance so to minimize costs and maximize processes; thus; searching for a better appreciation of human management in their processes.

Another important point to be highlighted in this article is that before implementing the computational model, data remained totally disperse, that is to say, no information integration was available. Resulting in an excessive time demand for managers while analyzing a problem, consequently, delaying decision-making, as shown in a diagram form by Figure 5 below:

\section{Scenario A: The process prior to implementation of the computational model}

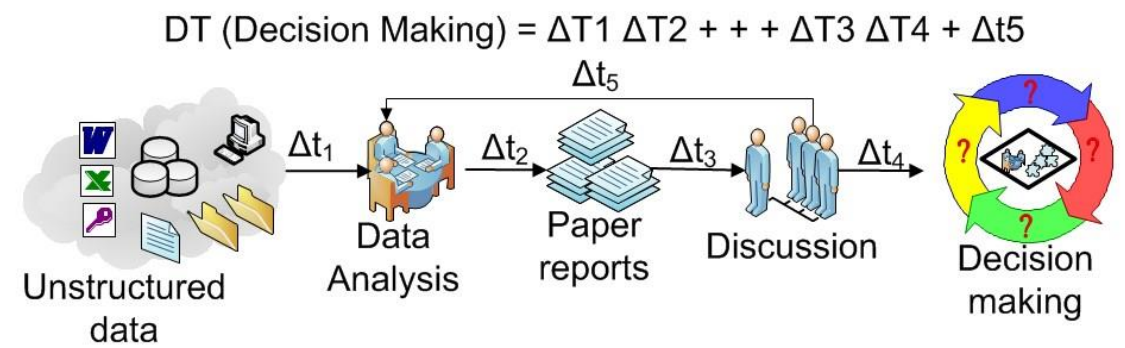

Scenario B: After the implementation of the computational model

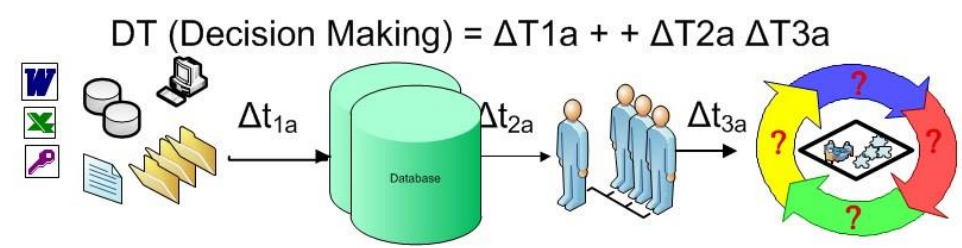

Figure 5 - Scenario for Before and After Implementing Computational Model.

Source: Authors, 2010

It became clear that many of the gathered variables by the new system were minimized and surveyed, as for instance, the feature "decision-making duration" which in the past, because of information dispersion, was most tardy. With the new computational model we have regained around a $40 \%$ "speed of response to failure".

With this new computational model, information is upgraded with speed since, while dealing with it, those professionals involved have become alert and aware of how to interpret what is going on, thus the employee knows how to proceed and monitor every happening. 


\section{FINAL CONSIDERATIONS}

Results in this paper have presented meaningful gains for operational issues, as well as for features related to fleet vehicle business procedures and management, mainly for the organization linked to the Interstate Road Transport System.

Another important aspect that deserves to be highlighted is the significant time decrease for decision-making. Time slackening for information withdrawal, data unification into a single and reliable repository, paper flux reduction for decisionmaking process and information dissemination to other fields of the organization have led to the strengthening of operational systems, maintenance and strategy itself.

Pertinent to the strategic question, it has become evident that the proposed computational model integrated to the Balanced Scorecard method was very useful, while implementing the Balanced Scorecard, where we have the possibility to diagnose failures and anomalies.

Related to strategy amid the surveyed company, what mostly called the managers' attention was the wastefulness resulting from a corrective maintenance. With the approach of maintenance centralized on reliability, conceived from the researcher's interface with the company, proposing statistically demonstrated indicators, all the wastefulness of the company became evident.

Within this context, the company has also started to search for new partners, that like them, work on a philosophy based on reliability, in such a manner that their corporate image may consolidate not only in their clients but also in their suppliers, in employees, and in all those participating in the productive chain. Then, it will be possible to work with new businesses and service goods aimed at farthest places, for instance, offering trips to Brazil's neighbor countries, while collecting and distributing goods fortransportat services scheduled in the same trip, thus benefiting from the same vehicle for the service. This was due to a decrease of vehicle breakdowns and guaranteed fleet availability, enabling a wide and new range of business offers.

Regarding internal processes, this survey has been of determinant impact on the managerial decision-making process of the company, while verifying the possibility of consolidating proper tools for decision-making support, as well as the implementation of Managerial Information Systems together with management Indicators.

While analyzing "People's" perspective, managers realized the urgency to entitle employees; develop citizens; provide stimulus and participation. This is a natural process, since when various tools are proposed where information is supplied, there still remains the need to delegate to employees, so that they may interpret data and information and also be able to execute.

The oldest employees should be properly trained, since most of them still bring with themselves the mentality that all this progress going on is only a trend and/or that everything has always worked that way and will continue the same.

Yet amid this strategic scenario, a new computational model has given strategic mobility to the company in order to simulate results, preview failure tendencies and model new environments.

Another significant outcome for this survey, deals with accessibility simulation and analysis for synthetic data as well as for data analytical sampling. Computational 
tools carry deep insight on business intelligence, thus aiding with simulations and queries generated through an OLAP search and favoring access to key performance indicators of the company.

Perhaps, it may be affirmed that the initially proposed objectives for this paper have been attained and that adopting the hereby dealt with computational resources, supported by the case study, have brought competitive advantages to business and to the environment among which this survey was carried out.

\section{LIMITATIONS AND SUGGESTIONS}

Amid continuity possibilities for the same research line, surveys that enable a deep analysis on reliable strategic indicators in different surroundings may be enhanced as appropriate.

Another continuity possibility for this survey is related to knowledge management application for RCM systems through software and modeling supported by decision-making as its primary tool.

Increasing the number of evaluated variables for the Data Warehouse model, or else trying to understand a new model of Information Load that enables diminishing data loading duration and quality of generated data are all also possibilities for enlarging this research.

Still further in this aspect, it is recommended that the proposed model may be compared to other computational tools focused on business management linked to maintenance, as for instance; Reliability Engineering (Weibull distribution), RCM, MCC, XFMEA.

Lastly, trying to implement an RCM process with knowledge systems like CommonKADS, which stimulates integration between software engineering and knowledge engineering, suggests other research lines.

\section{REFERENCES}

Almeida Junior., J. R. (2003). Segurança em Sistemas Críticos e em Sistemas de Informação: Um Estudo Comparativo, São Paulo, 191 p. Tese - Escola Politécnica da Universidade de São Paulo.

Campos, F. C., (1999). Proposta de interface para apoio à gestão da manutenção de frotas de Veículos. São Carlos, 247 p. Teses (Doutorado) - Escola de Engenharia de São Carlos, Universidade de São Paulo.

Elmasri, R.; Navathe, S. B. (2002). Sistemas de banco de dados: fundamentos e aplicações. Rio de Janeiro: LTC.

Gil, A. C. (2002). Como elaborar projetos de pesquisa. São Paulo: Atlas.

Godoy, E. P. (2007). Desenvolvimento de uma ferramenta de análise de desempenho de redes CAN (Controller Area Network) para aplicações em sistemas agrícolas. Dissertação (Mestrado em Engenharia) - Escola de Engenharia de São Carlos, Universidade de São Paulo. São Carlos. 
IEC - Functional Safety Electrical/Electronic/Programmable - IEC 61508-1 STD 41997 . (1997). Electronic Safely Related Systems. International Electrotechnical Comission.

Inmon, W. H.; Hackarthorn, R. D. (1997). Como usar o Data Warehouse. Rio de Janeiro: IBPI Press.

JQME, Journal Of Quality In Maintenance Engineering. (2010). Maintenance Information Systems, in Emeral, ISSN 1355-2511, January.

Kaplan, R. S.; Norton, D. P. (1997). A estratégia em ação: balanced scorecard. Rio de Janeiro: Elsevier.

. (2000). A organização orientada para a estratégia: como as empresas que adotam o balanced scorecard prosperam no novo ambiente de negócios. Rio de Janeiro: Campus.

Kimball, R. (1998). Data Warehouse. São Paulo: Makron Books.

Marçal, R. F. M.; Susin, A. A. (2005). Detectando falhas incipientes em máquinas rotativas. Revista Gestão Industrial. 1(21), p. 87.

Miguel, P. A.C. (org.) (2010). Metodologia de pesquisa em engenharia de produção e gestão de operações. Rio de Janeiro: Elsevier.

Nunes, E. L.; Valladares, A. (2002). Potencialidades da MCC para a gestão integrada da manutenção e da mudança de organizações. XXII Encontro Nacional de Engenharia de Produção Curitiba - PR, 23 a 25 de outubro de 2002.

O’brien, J. A. (2008). Sistemas de informação e as decisões gerenciais na era da internet. São Paulo: Saraiva.

Oliveira, A., (2010). Análise inteligente de falhas para apoiar decisões estratégicas em projetos críticos, Tese apresentada na Universidade de São Paulo.

Pinto, A. K.; Xavier, J. N. (2001). Manutenção: função estratégica. Rio de Janeiro: Qualitymark.

Rausand, M.; Hoyland, A. (2004). System reliability theory: models, statistical methods and applications. N. York: Wiley.

Santos, J. E., (2001). Considerações sobre o processo de manutenção para empresas operadoras de ônibus urbanos de porte médio. Brasília, 177 p. Dissertação de Mestrado - Universidade de Brasília.

Singh, H. S. (2001). Data Warehouse: conceitos, tecnologias, implementação e gerenciamento. São Paulo: Makron Books.

Siqueira, I. P. (2009). Manutenção centrada na confiabilidade: manual de implementação. Rio de Janeiro: Qualitymark.

Slack, N.; Chambers, S.; Johnston, R. (2007). Administração de Produção. São Paulo: Atlas.

Sommerville, I. (2007). Engenharia de Software. São Paulo: Addison Wesley.

Son, Y. T.; Kim, B. Y.; Park, K. J.; Lee, H. Y.; Kim, H. J.; Suh, M. W. (2009). Study of RCM-based maintenance planning for complex structures using soft computing technique. International Journal of Automotive Technology.10(5), p.635-644. 
Souza, S. S.; Lima, C. R. C. (2003). Manutenção Centrada em Confiabilidade como ferramenta estratégica. XXIII Encontro Nac. de Eng. de Produção - Ouro Preto, MG, Brasil.

Villemeur, A. (1992). Reliability, Availability, Maintainability and Safety Assessment. Assessment, Hardware, Software and Human Factors. John Wiley \& Sons. 